\title{
Estimation of Acreage Response of Major Crops in Haryana using Co-integration Approach
}

\author{
Vikas $^{1 *}$, Veena Manocha ${ }^{2}$ and S.K. Goyal ${ }^{2}$ \\ ${ }^{1}$ ICAR-National Bureau of Soil Survey and Land Use Planning, Regional Centre, \\ IARI Campus, New Delhi-110 012, India \\ ${ }^{2}$ CCSHAU, Hisar, Haryana, India \\ *Corresponding author
}

\begin{abstract}
A B S T R A C T
The present study is an attempt to estimate the acreage response functions for major crops in Haryana within the framework of co integration and error correction model and to

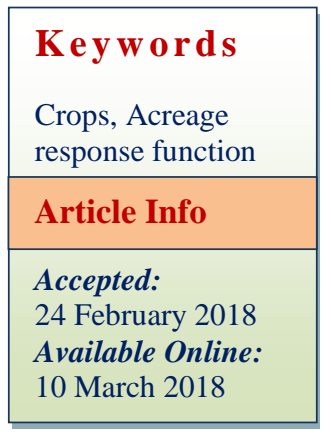
compare the short-run and long-run supply elasticities of major crops. The long-run acreage response to lagged price was positive and significant in the case of rice, rapeseedmustard and sugarcane with elasticity values $0.19,0.22$ and 0.29 , respectively. In case of other crops except bajra and gram, very low positive but non-significant price elasticities have been observed. In the short-run, lagged price elasticities were found to be positive for all the crops. However, the positive significant values have been observed in case of rapeseed-mustard, sugarcane and bajra only. The long-run acreage response to lagged year yield was found to be positive and significant in case of rice, wheat and cotton (Am.) with elasticity values $0.26,0.18$ and 0.29 , respectively. Irrigation elasticity has been observed to be positive for all the crops in the long-run, while it is positive for all the crops except gram and rapeseed-mustard in the short-run. However, only wheat and sugarcane are found to be positively and significantly responsive to irrigation in the long-run as well as short-run.
\end{abstract}

\section{Introduction}

Agriculture in most of the developing countries is the largest commodity producing sector: in terms of its contribution to GDP, employment of labour force and providing means of livelihood to a large section of the population. One of the most important issues in the agricultural economic development is supply response. The issue of agricultural supply response to price and non-price factors has been widely studied in the literature.
According to Nerlove and Bachman (1960), research on supply response is to improve the understanding of the price mechanism. Besides prices, there are various other nonprice factors such as weather, irrigation, technology etc. that also influence supply. The supply response equations can be used to forecast the agricultural supplies in the future. During the last five decades, a large volume of literature on supply response indicated that the response is much weaker. Non-price factors seem to dominate over price factors in 
farmers' decision problem (Krishna, 1963; Krishna and Rao, 1967; Maji et al., 1971; Cummings, 1975; Askari and Cummings, 1977; Narayana et al., 1981; Rao, 2004 and Mythili, 2008).

The previous studies on agricultural supply response in India and abroad used time series data and panel data, within the Nerlovian dynamic models framework (1958), which included lagged values of the dependent variable on the right hand side of the estimating equation, the error terms of the estimated equations were postulated to be in auto-regressive structure. The OLS should not be used in such a case because combination of lagged dependent variable and auto correlated errors renders OLS inconsistent (Johnston and DiNardo, 1997).

Another concern in the supply response is the underlying assumption of stationarity of the data generating process. However, time series data generally have a unit root problem. If this is the case, traditional regression analysis with the unit root problem leads to the spurious regression (Gujrati, 1995; Greene, 2008). Cointegration analysis can be used with nonstationary data to avoid spurious regressions (Banerjee, et al., 1993) when combined with error correction models; it offers a means of obtaining consistent yet distinct estimates of both long-run and short-run elasticity.

The majority of the studies in the Indian context have been undertaken for aggregate agricultural supply response at the country level. In India, the public investments during the past three to four decades were relatively higher and the level of infrastructure in general and irrigation in particular is also high in some states like Punjab, Haryana, Uttar Pradesh and Andhra Pradesh. Micro level studies taking the case of a single crop have shown high responsiveness to price as well as non-price factors like technology and infrastructure. Therefore, it is obvious that supply response behavior depends on regionspecific characteristics. Keeping in view the above facts, a need is felt to estimate the acreage response functions and to compare the short-run and long-run supply elasticities of major crops in the state of Haryana using cointegration and error correction model approach.

\section{Materials and Methods}

The present study is confined to the state of Haryana because the area is fairly homogenous in farming type, it has adopted the new farm technology to a great extent, and it has recorded a phenomenal growth in agricultural production. The period of study starts from the year 1966-67 which coincides with the creation of Haryana state after bifurcation of erstwhile Punjab state and ends to the year 2008-09.

The time series data for the period 1966-67 to 2008-09 on area, production, productivity of major crops (Rice, wheat, bajra, gram, rapeseed \& mustard, cotton american, cotton desi and sugarcane), area irrigated, harvest prices, rainfall and rural literacy were collected mainly from the statistical abstracts of Haryana published by the Economic and Statistical Advisor, Govt. of Haryana and other published sources. The collected data were used to estimate the acreage response functions for crops as per objectives of the study.

\section{Analytical framework}

Since the appearance of Nerlove's work 55 years ago, most studies on agricultural supply response have relied on dynamic econometric supply functions estimated directly from time series data. Nerlove (1958) model captures the dynamics of agriculture by incorporating price expectation and/or adjustment costs. 
In the Nerlove price expectations model, the desired output $Y_{t}^{*}$ is a function of price expectations $P_{t}^{e}$ so that the supply function can be represented as

$Y_{t}^{*}=a+b P_{t}^{e}+u_{t}$

Where, $b$ is the long-run elasticity of output with respect to price. Assuming that price expectations are adaptive, then

$P_{t}^{e}-P_{t-1}^{e}=\delta\left(P_{t-1}-P_{t-1}^{e}\right)$

Where, $P_{t-1}$ is actual price in period $t$-1. Also assuming that $Y_{t}^{*}=Y_{t}$ i.e. desired output is equal to realized output $Y_{t}$ in equilibrium and substituting $Y_{t}$ for $Y_{t}^{*}$ and $P_{t}^{e}$ from equation (2.2) into equation (2.1) gives (for manipulations see for example, Lim, 1975)

$Y_{t}=a \delta+b \delta P_{t-1}+(1-\delta) Y_{t-1}+\delta u_{t}$

This implies that output supplied can be expressed as a function of its own lagged value and lagged price as in equation (2.3) with the short run elasticity $b \delta$.

Alternatively, the supply function can be derived from the partial adjustment perspective, i.e. the actual change in output in a period is a fraction $\alpha(0<\alpha<1)$ of the change required to achieve the desired output $_{t}^{*}$. Thus,

$$
Y_{t}=\alpha Y_{t}^{*}+(1-\alpha) Y_{t-1}
$$

Assuming that $P_{t}^{e}=P_{t-1}$ and substituting equation (2.4) into equation (2.1) gives
$Y_{t}=a \alpha+b \alpha P_{t-1}+(1-\alpha) Y_{t-1}+\alpha u_{t}$

Thus the output supplied is expressed as a function of its lagged value and the lagged price, just as in equation (2.3).

From both equations (2.3) and (2.5), the reduced form of the supply function in the Nerlove model is:

$Y_{t}=\beta_{0}+\beta_{1} P_{t-1}+\beta_{2} Y_{t-1}+v_{t}$

Short run Elasticity w.r.t. price $=\beta_{1}$

Long run Elasticity w.r.t. price $=\frac{\beta_{1}}{1-\beta_{2}}$

The variants of the Nerlovian approach including other independent variables in the equation (2.6), using multivariate regression techniques to estimate supply response elasticities are popular among researchers (Johnston, 1984; Sadoulet, E. and A. de Janvry, 1995). But the present study uses cointegration analysis and its implied error correction model (ECM) to overcome the problems usually encountered with the use of the traditional Nerlovian model.

\section{Specification of the model and variables}

The standard procedure to model supply response is a two stage approach. First farmers allocate land based on the expected prices. In the second stage yield is determined based on other inputs and climate variables given the area. It is hypothesized that farmers make substantial revisions in the decision on other inputs after the area allocation is made and the input changes will be reflected overall in the deterministic component of the yield. Hence it is reasonable to assume that the area is influenced by expected price of the output. Assuming that these factors will be reflected 
in yield, the acreage response function has been specified in our model as a function of lagged price, lagged yield, lagged irrigation and lagged area.

Various studies attributed problems in measurement of variables and the methodologies used for estimation as reasons for highly varying elasticities even within a region. On the basis of the literature, this study used three variants of price variable viz. harvest price, harvest price of substitute/competing crop and relative price (ratio of harvest price of the crop to the harvest price of substitute/competing crop).

Regarding rainfall variable, so far no satisfactory measure of this variable has been found in the literature. Variables used in the studies are Average quantum of total rainfall in a crop season, rainfall in pre sowing period, absolute deviation from normal rainfall, frequency of number of stations reported below $20 \%$ normal to total in a region.

So the rainfall in pre sowing period was tried in area response function. One year lagged yield is assumed to represent the expected yield in the next year. In resource allocation, decision is based upon farmer's reaction in which case the immediate past yield may weigh heavily and hence last year's yield is considered adequate to represent expected yield. Irrigated area under the crop is also taken as a proxy for technology.

The long-run acreage response function used in the study is as follows:

$$
\begin{aligned}
& \operatorname{LnA}_{i t}= \\
& \beta_{i 0}+\beta_{i 1} \operatorname{LnHP}_{i t-1}+\beta_{i 2} \operatorname{LnHPS}_{i t-1}+\beta_{i 3} \operatorname{LnY}_{i t-1}+\beta_{i 4} \operatorname{LnR}_{1, i t-1} \\
& +\beta_{i 5} \operatorname{LnI}_{i t-1}+\beta_{i 6} \operatorname{LnA}_{i t-1}+\varepsilon_{a, i t} \text { (2.7) }
\end{aligned}
$$

Where the subscript $i$ stands for different crops.
$\operatorname{Ln} A_{i t}=$ the natural log of area planted under the $i^{\text {th }}$ crop in the $t^{\text {th }}$ year.

$\operatorname{LnHP}_{i t-1}=$ the natural log of lagged harvest price of the $i^{t h}$ crop.

$\operatorname{LnHPS}_{i t-1}=$ the natural log of lagged harvest price of the substitute crop for $i^{\text {th }}$ crop.

$\operatorname{Ln} Y_{i t-1}=$ the natural log of lagged average yield of the $i^{t h}$ crop.

$L n R_{1, i t-1}=$ the natural log of pre sowing month rainfall of the $i^{\text {th }}$ crop.

$\operatorname{LnI}_{i t-1}=$ the natural log of lagged irrigated area under the $i^{\text {th }}$ crop.

$\operatorname{Ln} A_{i t-1}=$ the natural log of lagged area under the $i^{\text {th }}$ crop.

$\beta_{i 1}, \beta_{i 2}, \beta_{i 3}, \beta_{i 4}, \beta_{i 5}$ and $\beta_{i 6}$ are the longrun coefficients of the $i^{\text {th }}$ crop and $\varepsilon_{a, i t}$ are the error terms assumed to be white noise.

The substituting/competing crop(s) for individual crops are: wheat for gram, rapeseed-mustard for sugarcane; gram for wheat; maize for rice; cotton (D) for cotton (Am); cotton (Am) for cotton (D) and jowar for bajra.

\section{Model implementation techniques}

In this method, the first stage involves a preliminary analysis to find the order of integration of the data series and after that ordinary least squares regression is carried out to estimate the equations for those economic 
aggregates, where co-integration can be found (Engle \& Granger, 1987; Adam, 1992). These are the stationary test (unit root test) and cointegration test, respectively. In the second stage, the residuals obtained in the long-run co-integration regression are used as explanatory variable to specify a dynamic error correction model, which is estimated via ordinary least squares (OLS) regression.

\section{Test for stationarity (Unit root test)}

Consider the simple first order autoregressive, AR (1) model $Y_{t}=\alpha+\rho Y_{t-1}+{ }^{u_{t}}$. A series $Y_{t}$ is stationary where $\left.\right|^{\rho} \mid<1$ and has a mean, variance and autocorrelation that is constant over time, implying that the error structure is time invariant (Adam, 1992; Tambi, 1999; Niemi, 2003). In contrast, a non-stationary series is one where $\left.\right|^{\rho} \mid \geq 1$. It has a variance, which is asymptotically infinite; the series rarely crosses the mean and innovations to the series are permanent. That is any stochastic shock may not return to a proper mean level.

A classic example of a non-stationary series is a random walk where $\rho_{\mid=1}$. Thus, $Y_{t}$ is said to be integrated of order $I$ (1). Since $\rho$ is unity, $Y$ is said to have a "unit root".

To carry out the unit root test for stationarity, we used the Augmented Dickey-Fuller (ADF) test to examine each of the variables for the presence of a unit root (an indication of nonstationarity), since the Dickey-Fuller (DF) test assumes that the data generating process (DGP) is a first order autoregressive (AR(1)) process. Thus if the DGP is a higher process, autocorrelation in the error term will bias the test. So the ADF is used to avoid such bias in the test since it includes the first difference in lags in such a way that the error term is distributed as white noise. The test formula for the $\mathrm{ADF}$ is shown in equation (2.8) below.

$$
\Delta Y_{t}=\alpha+\rho Y_{t-1}+\sum_{i=1}^{j} \gamma \Delta Y_{t-i}+u_{t}
$$

Where $Y$ is the series to be tested $\rho$ is the test coefficient and $\mathrm{j}$ the lag length chosen for ADF such that $u_{t}$ is empirical white noise. Here the significance of $\rho$ is tested against the null that $\rho=0$, based on estimated value of $\rho$ obtained from the OLS estimate of equation (2.8). Thus if the null hypothesis of non-stationarity cannot be rejected, the variables are differenced until they become stationary, that is until the existence of a unit root is rejected, before proceeding to test for co integration.

\section{Test for co-integration}

In testing for co integration, we apply the $\mathrm{ADF}$ test to the residuals of the co-integrating regression rather than the levels of the series. If the residuals of the bivariate or multivariate co-integrating regressions are found to be stationary, implying co integration, we then specify an error correction model, which is the second step of the Engle-Granger two-step method. The ADF test equation based on the residuals obtained from equations (2.7) and (2.8) is as follows:

$\Delta \hat{\varepsilon}_{t}=\phi+\beta \hat{\varepsilon}_{t-1}+\sum_{t-1}^{j} \lambda \Delta \hat{\varepsilon}_{t-j}+v_{t}$

The test statistic, as indicated earlier, is a tratio for $\beta=0$. If this null hypothesis cannot be rejected against the alternative that $\beta<0$, then the variables are not co integrated, on the other hand if the null hypothesis is rejected then the conclusion would be that the estimated $\varepsilon_{t}$ is stationary (that is, does not have a unit root). In our estimations, bivariate and multivariate co-integrating regressions 
were carried out between the area of major crops and the different explanatory variables specified in equation (2.7) to establish the existence of long-run co integrating relationship. Finally, in stage two, the residuals of the valid multivariate cointegrating regressions were included in the model as explanatory variable, before it was estimated with the use of ordinary least squares regression. The error correction model (ECM) for acreage response can be specified as follows:

$$
\begin{aligned}
& \Delta L n A_{i t}= \\
& \alpha_{i 0}+\alpha_{i 1} \Delta L n H P_{i t-1}+\alpha_{i 2} \Delta L n H P S_{i t-1}+\alpha_{i 3} \Delta L n Y_{i t-1}+\alpha_{i 4} \Delta L n R_{2, i t-1} \\
& +\alpha_{i 5} \Delta L n I_{i t-1}+\alpha_{i 6} \Delta L n A_{i t-1}+\lambda_{a, i} \hat{\varepsilon}_{a, i t-1}+v_{a, i t}
\end{aligned}
$$

Where, all the variables are as earlier defined in equation (2.7) and $\Delta$ is the first difference operator, while $\alpha_{i 1}, \alpha_{i 2}, \alpha_{i 3}, \alpha_{i 4}, \alpha_{i 5}$, and $\alpha_{i 6}$ are the short-run coefficients and $\lambda_{a, i}$ is the error correction coefficient related with $i^{\text {th }}$ crop that measure the speed of adjustment from short-run disequilibrium to long-run steady state equilibrium. $v_{a, i t}$ are error terms assumed to be distributed as white noise.

\section{Results and Discussion}

\section{Pattern of area, production and average yield of major crops in Haryana}

The figures in Table 1 revealed that the total cropped area (TCA) of the state increased from about 4600 thousand hectares during the period 1966-68 to 6455 thousand hectares during the last period i.e. 2006-2008.

But this increase in area was not proportionately shared by all crops as it is evident from the percentage share of individual crops.
It has been observed that the share of food grains which initially increased significantly in the initial years of green revolution came down from nearly 78 per cent in the triennium 1976-78 to about 69 per cent during triennium 2006-08. The area under all cereals increased from about 54 per cent to about 67 per cent over the periods of study in which the main contribution comes from rice and wheat together. The percentage share of wheat and rice in TCA increased from 23 per cent in 1966-68 to about 55 per cent in 2006-08. Coarse cereals like jowar, maize, bajra and barley registered a decline in their percentage shares in TCA to such as extent that their absolute areas have also decreased drastically. The area under pulses which was nearly 22 per cent in the beginning period has reduced to a negligible level of only 3 per cent. The area under pulses has decreased partially on account of no major breakthrough in levels of yields. Thus, the total area under food grains observed a declining trend mainly due to fall in area under pulses. The area under oilseeds and American cotton observed an increasing trend over the years. It has been observed from the last column of the table, that during the overall period of study, rice, wheat and cotton recorded the highest increase in acreages. This period was also accompanied by a marked increase in the irrigated area. The percentage of gross irrigated area in TCA increased from nearly 37 per cent in 1966-68 to about 87 per cent in 2006-08. This indicates that increase in irrigation may be an important factor in explaining changes in the acreage under these crops. As the share of area under coarse cereals like jowar, maize and barley in TCA declined from about 12 per cent in the period 1966-68 to merely 2 per cent during the last period i.e. 2006-08, these crops were not included in further analysis of the study.

In Table 2 it is observed that regarding cereals, highest increase in production was recorded in rice followed by wheat and bajra 
while production of maize and barley declined during the periods of study. The dramatic increase in production of rice and wheat over the years was mainly due to increase in acreage under these crops and improved yield levels while in spite of decline the area under the bajra crop, its production observed an increase of about 207 per cent which may be due to high yielding varieties and better irrigation facility. The production of total food grains in the state increased from about 31 lakh tonnes to about 154.12 lakh tonnes, thus registering an increase of about 396 per cent. However, the production of total pulses observed a declining trend over the periods mainly due to decline in area and no significant breakthrough in yield level of pulse crops.

Regarding non-food grains, rapeseed-mustard and cotton (Am) observed a many fold increase in production. The production of rapeseed-mustard increased from a low level of 72 thousand tonnes in 1966-68 to 765.30 thousand tonnes in 2006-08, thus registering an increase of 963 per cent. The same observation was recorded in case of cotton (Am) which registered an increase of 781 per cent in the production. Cotton (D) and sugarcane production also observed an increasing trend during the periods of study. Average yield of major crops during the periods of study has been provided in Table 3. The results in the table revealed that average yield of all crops except gram recorded an increasing trend.

The average yield of rice and wheat increased from initial levels of $1224 \mathrm{~kg} / \mathrm{ha}$ and 1613 $\mathrm{kg} / \mathrm{ha}$ to $3109 \mathrm{~kg} / \mathrm{ha}$ and $4335 \mathrm{~kg} / \mathrm{ha}$, respectively over the years. The highest percentage increase in productivity was observed in case of bajra followed by rapeseed-mustard. The average yield of bajra increased from a marginal level of $400 \mathrm{~kg} / \mathrm{ha}$ to a significant high level of $1754 \mathrm{~kg} /$ ha and that of rapeseed-mustard increased from 441 $\mathrm{kg} / \mathrm{ha}$ to $1423 \mathrm{~kg} / \mathrm{ha}$. A significant jump in the average yield of both cotton (Am) and cotton (desi) has been observed in the period 200608. The average yield has almost doubled in case of cotton (Am) and slightly less than doubled in case of cotton (desi) as compared to the previous two decades. During the last five decades, gram was the only crop whose yield level had remained more or less the same.

\section{Unit root test for stationarity}

The Augmented Dickey Fuller (ADF) test was conducted to test the stationary nature of the time series data of all the variables for each crop. Lag length for the ADF test is selected so as to make Aikaike information criteria (AIC) value minimum. It reports the test results of the individual series (in logarithms) for unit root using the ADF test both with intercept and trend for all the major crops considered for the study. It has been observed from the results that different patterns regarding unit root problem exist in different crops. It has been observed that for rice crop the variables like area, production, harvest price, relative yield, irrigated area under the crop have a unit root problem at level form and stationary at differenced form whereas the yield, relative price, and rainfall harvest season were stationary at their level form. Thus the data series regarding area, production, harvest price, relative yield and irrigated area are integrated of order one.

Regarding bajra crop, it is evident from the table that all the variables except area were stationary at their level form. However, area variable was stationary at differenced form. In the case of wheat crop, the variables like production yield, harvest price and relative price were integrated of order one at their level form, however these variables were integrated of order zero at their differenced 
form whereas harvest price of substitute, relative yield, rainfall and irrigated area were stationary at their level form. All the variables in case of gram (except relative price, harvest price of substitute and irrigated area) were not having unit root problem, implying that they were $I(0)$. However, in case of rapeseedmustard area, production, yield, relative yield and rainfall were $I(0)$ at the level form while harvest price, relative price, harvest price of substitute, and irrigated area had unit root problem at their level form but after differencing, they were stationary.

The data series regarding area, production, harvest price, relative price, harvest price of substitute, and irrigated area were stationary at differenced form in case of American cotton as well as desi cotton. However, the other variables did not appear to have unit root problem. So far as sugarcane crop is concerned, the data series regarding area, production, harvest price of substitute, and irrigated area, were free of unit root problem in their differenced form, while the remaining variables were observed to be stationary at their level form.

\section{Engle and Granger co-integration tests}

The results of the bivariate co-integration regression between area under the respective crop and each of the other explanatory variables explained that the estimated ADF was observed to be significant in case of lagged irrigated area (except bajra) and lagged area for all the crops, implying the rejection of null hypothesis of no co integration. Thus, there existed a long-run relationship between these variables and the dependent variable i.e. area under the respective crops. However, the long-run relationship between area and lagged harvest price was observed to be significant only in case of gram, rapeseed-mustard and cotton (Am.). Regarding relationship between area and lagged yield, co-integration had been observed in case of rice, wheat, rapeseedmustard and cotton (Am).

\section{Estimated acreage response functions}

Several specifications were experimented for estimation of acreage response functions of major crops taking different explanatory variables as detailed in chapter three. A comparative analysis of the several specifications revealed that the multiple co integration regressions between area and the explanatory variables like lagged harvest price, lagged yield, lagged irrigated area and lagged area for the considered crops, have shown better explanatory powers as well as theoretically justifiable parameter coefficients. However, the variables pre sowing month rainfall and harvest price of substitute crop were having contrary signs and nonsignificant values, therefore, these variables were not considered in the final acreage response equations. A glance at the results indicated that most of the explanatory variables have expected signs and explanatory power of the equations were satisfactory except in case of sugarcane. The Augmented Dickey Fuller (ADF) statistic was computed for the residuals obtained from these multiple regressions. The estimated ADF statistic were found to be significant in all the crops, thus rejecting the null hypothesis of no co integration between the area and considered explanatory variables and implied a valid long-run relationship. After the long-run relationship has been confirmed, an error correction model (ECM) as provided in equation (2.10) including only those explanatory variables which have been finally considered in the long-run co integration and the lagged residuals obtained from these multiple co integrating regressions as an additional explanatory variable was developed. The results of the estimated ECM for acreage response along with long-run coefficients are shown in Table 4. 
Table.1 Area under major crops in Haryana (Thousand hectares)

\begin{tabular}{|l|}
\hline Crop \\
\hline Rice \\
\hline Jowar \\
\hline Bajra \\
\hline Maize \\
\hline Wheat \\
\hline Barley \\
\hline Total Cereals* \\
\hline Gram \\
\hline \hline Total Pulses \\
\hline Total Foodgrains** \\
\hline Rapeseed-mustard \\
\hline Total Oilseeds \\
\hline Cotton A \\
\hline Cotton D \\
\hline Total Cotton \\
\hline Sugarcane \\
\hline Total crops \\
\hline
\end{tabular}

\begin{tabular}{|c|c|c|c|c|}
\hline \multicolumn{5}{|c|}{ Period (Triennium) } \\
\hline $1966-68$ & $1976-78$ & 1986-88 & 1996-98 & 2006-08 \\
\hline $212.67(4.62)$ & $386.40(7.14)$ & $564.67(10.35)$ & $943.40(15.27)$ & $1108.57(17.17)$ \\
\hline $257.00(5.59)$ & $167.77(3.10)$ & $146.77(2.69)$ & $129.87(2.10)$ & $86.93(1.35)$ \\
\hline $884.00(19.21)$ & 901.77 (16.66) & $681.67(12.50)$ & $589.33(9.54)$ & $619.97(9.60)$ \\
\hline $96.67(2.10)$ & $102.40(1.89)$ & $46.20(0.85)$ & $23.93(0.39)$ & $12.73(0.20)$ \\
\hline $827.33(17.98)$ & $1396.77(25.80)$ & $1780.13(32.64)$ & $2087.33(33.78)$ & 2433.07 (37.69) \\
\hline $216.33(4.70)$ & $96.73(1.79)$ & $65.27(1.20)$ & $37.37(0.60)$ & $43.40(0.67)$ \\
\hline $2496.00(54.25)$ & $3055.60(56.45)$ & $3288.00(60.29)$ & 3811.77 (61.69) & $4306.80(66.72)$ \\
\hline $933.00(20.28)$ & $1080.43(19.96)$ & $485.50(8.90)$ & $352.00(5.70)$ & $112.87(1.75)$ \\
\hline $1033.67(22.46)$ & $1153.13(21.30)$ & $557.60(10.22)$ & $419.87(6.80)$ & $175.13(2.71)$ \\
\hline $3529.67(76.72)$ & $4208.73(77.75)$ & $3845.60(70.52)$ & $4231.63(68.48)$ & $4481.93(69.43)$ \\
\hline $170.00(3.70)$ & $133.33(2.46)$ & $331.33(6.08)$ & 555.57 (8.99) & $536.20(8.31)$ \\
\hline $186.33(4.05)$ & $146.67(2.71)$ & $341.53(6.26)$ & $604.97(9.79)$ & $551.70(8.55)$ \\
\hline $114.67(2.49)$ & $149.27(2.75)$ & $338.17(6.20)$ & $443.73(7.18)$ & $427.73(6.63)$ \\
\hline $97.33(2.12)$ & $115.50(2.13)$ & $71.93(1.32)$ & $178.70(2.89)$ & $61.03(0.94)$ \\
\hline $212.00(4.61)$ & $264.77(5.75)$ & $410.10(8.91)$ & $622.43(13.53)$ & $488.77(10.62)$ \\
\hline $143.67(3.12)$ & $182.77(3.38)$ & $132.83(2.44)$ & $143.77(2.33)$ & $123.83(1.92)$ \\
\hline $4071.67(88.50)$ & $4802.93(88.07)$ & $4730.07(87.33)$ & $5602.80(90.27)$ & $5646.23(87.47)$ \\
\hline $4600.67(100.00)$ & $5413.00(100.00$ & $5453.33(100.00)$ & $6179.00(100.00$ & $6455.00(100.0$ \\
\hline
\end{tabular}

\begin{tabular}{|c|}
\hline $\begin{array}{c}\text { \% change in 2006-08 } \\
\text { over 1966-68 }\end{array}$ \\
\hline 421.27 \\
\hline-62.17 \\
\hline-29.87 \\
\hline-86.83 \\
\hline 194.08 \\
\hline-79.94 \\
\hline 72.55 \\
\hline-87.90 \\
\hline-83.06 \\
\hline 26.98 \\
\hline 215.41 \\
\hline 196.08 \\
\hline 273.02 \\
\hline-37.29 \\
\hline 130.55 \\
\hline-13.80 \\
\hline 38.67 \\
\hline 40.30 \\
\hline
\end{tabular}

*Area under total cereals is the sum of areas under rice, bajra, jowar, maize, wheat, barley and other cereals.

**Area under food grains is the sum of areas under total cereals and total pulses.

Table.2 Production of major crops in Haryana (Thousand tonnes)

\begin{tabular}{|l|}
\hline Crop \\
\hline Rice \\
\hline Jowar \\
\hline Bajra \\
\hline Maize \\
\hline Wheat \\
\hline Barley \\
\hline Total Cereals \\
\hline Gram \\
\hline Total Pulses \\
\hline Total Food grains \\
\hline Rapeseed-mustard \\
\hline Total Oilseeds \\
\hline Cotton A* \\
\hline Cotton D* \\
\hline
\end{tabular}

Sugarcane

\begin{tabular}{|c|c|}
\hline $\mathbf{1 9 6 6 - 6 8}$ & $\mathbf{1 9 7 6 - 7 8}$ \\
\hline 260.67 & 1002.67 \\
\hline 44.00 & 28.00 \\
\hline 354.67 & 405.33 \\
\hline 92.67 & 95.33 \\
\hline 1342.00 & 2992.67 \\
\hline 238.67 & 132.00 \\
\hline 2332.67 & 4656.00 \\
\hline 739.67 & 944.33 \\
\hline 776.00 & 988.77 \\
\hline 3105.33 & 5644.77 \\
\hline 72.00 & 78.00 \\
\hline 85.33 & 90.90 \\
\hline 189.00 & 331.33 \\
\hline 143.90 & 182.67 \\
\hline 550.00 & 771.33 \\
\hline
\end{tabular}

\begin{tabular}{|c|c|c|}
\hline Period (Triennium) & \multicolumn{1}{|c|}{} \\
\hline $\mathbf{1 9 8 6 - 8 8}$ & $\mathbf{1 9 9 6 - 9 8}$ & $\mathbf{2 0 0 6 - 0 8}$ \\
\hline 1354.33 & 2483.67 & 3426.67 \\
\hline 31.67 & 28.67 & 36.67 \\
\hline 474.33 & 647.33 & 1088.00 \\
\hline 47.67 & 44.33 & 30.33 \\
\hline 5381.00 & 7974.00 & 10550.33 \\
\hline 109.67 & 102 & 140.00 \\
\hline 7398.67 & 11280.00 & 15273.40 \\
\hline 361.33 & 293.00 & 91.00 \\
\hline 417.67 & 348.33 & 138.23 \\
\hline 7816.33 & 11628.33 & 15411.63 \\
\hline 343.03 & 625.67 & 765.30 \\
\hline 348.73 & 697.97 & 783.30 \\
\hline 707.33 & 874.33 & 1665.33 \\
\hline 105.67 & 288.33 & 184.33 \\
\hline 622.00 & 784.33 & 790.23 \\
\hline
\end{tabular}

\begin{tabular}{|c|}
\hline $\begin{array}{c}\text { change in 2006-08 } \\
\text { over 1966-68 }\end{array}$ \\
\hline 1214.58 \\
\hline-16.67 \\
\hline 206.77 \\
\hline-67.27 \\
\hline 686.16 \\
\hline-41.34 \\
\hline 554.76 \\
\hline-87.70 \\
\hline-82.19 \\
\hline 396.30 \\
\hline 962.92 \\
\hline 817.93 \\
\hline 781.13 \\
\hline 28.10 \\
\hline 43.68 \\
\hline
\end{tabular}

* Production of cotton is in thousand bales of $170 \mathrm{~kg}$ each.

Table.3 Average yield of major crops in Haryana $(\mathrm{kg} / \mathrm{ha})$

\begin{tabular}{|l|}
\hline Crop \\
\hline \hline Rice \\
\hline Jowar \\
\hline Bajra \\
\hline Maize \\
\hline Wheat \\
\hline Barley \\
\hline Gram \\
\hline Rapeseed-mustard \\
\hline Cotton A \\
\hline Cotton D \\
\hline
\end{tabular}

\begin{tabular}{|c|}
\hline $\mathbf{1 9 6 6 - 6 8}$ \\
\hline 1224 \\
\hline 167 \\
\hline 401 \\
\hline 944 \\
\hline 1613 \\
\hline 1138 \\
\hline 774 \\
\hline 441 \\
\hline 298 \\
\hline 272 \\
\hline
\end{tabular}

Period (Triennium)

\begin{tabular}{|c|c|}
\hline \multicolumn{3}{|c|}{ Period (Triennium) } \\
\hline 2586 & $\mathbf{1 9 8 6 - 8 8}$ \\
\hline 168 & 2392 \\
\hline 444 & 210 \\
\hline 946 & 636 \\
\hline 2138 & 1023 \\
\hline 1371 & 3017 \\
\hline 874 & 1680 \\
\hline 713 & 648 \\
\hline 376 & 939 \\
\hline 265 & 359 \\
\hline 4164 & 248 \\
\hline
\end{tabular}

\begin{tabular}{|r|}
\hline $\mathbf{1 9 9 6 - 9 8}$ \\
\hline 2669 \\
\hline 21 \\
\hline 110 \\
\hline 185 \\
\hline 3819 \\
\hline 2708 \\
\hline 83 \\
\hline 1118 \\
\hline 33 \\
\hline 28 \\
\hline
\end{tabular}

\begin{tabular}{|c|c|}
\hline $\mathbf{9 9 6}-\mathbf{9 8}$ & $\mathbf{2 0 0 6 - 0 8}$ \\
\hline 2669 & 3109 \\
\hline 219 & 400 \\
\hline 1100 & 1754 \\
\hline 1855 & 2531 \\
\hline 3819 & 4335 \\
\hline 2708 & 3009 \\
\hline 832 & 796 \\
\hline 1118 & 1423 \\
\hline 331 & 664 \\
\hline 280 & 502 \\
\hline
\end{tabular}

\begin{tabular}{|c|}
\hline \% change in 2006-08 over 1966-68 \\
\hline 153.96 \\
\hline 139.52 \\
\hline 337.49 \\
\hline 168.24 \\
\hline 168.79 \\
\hline 164.30 \\
\hline 2.89 \\
\hline 222.42 \\
\hline 123.18 \\
\hline 84.68 \\
\hline 64.61 \\
\hline
\end{tabular}


Table.4 Crop wise estimated error correction model for acreage response

\begin{tabular}{|c|c|c|c|c|c|c|c|c|}
\hline \multirow[t]{2}{*}{ Variable } & \multicolumn{8}{|c|}{ Short-run coefficients } \\
\hline & Rice & Bajra & Wheat & Gram & $\begin{array}{l}\text { Rapeseed- } \\
\text { Mustard }\end{array}$ & $\begin{array}{l}\text { Cotton } \\
\text { (Am.) }\end{array}$ & Cotton (desi) & Sugarcane \\
\hline Constant & 0.01 & -0.03 & -0.01 & -0.08 & 0.01 & 0.01 & -0.02 & 0.01 \\
\hline Ln $\Delta H P_{t-1}$ & $\begin{array}{l}0.02 \\
(0.10)\end{array}$ & $\begin{array}{l}0.18^{*} \\
(2.16)\end{array}$ & $\begin{array}{l}0.01 \\
(0.21)\end{array}$ & $\begin{array}{l}0.36 \\
(1.28)\end{array}$ & $0.40 *(2.60)$ & $0.16(1.30)$ & $0.22(1.42)$ & $\begin{array}{l}0.35^{*} \\
(2.52)\end{array}$ \\
\hline $\operatorname{Ln} \Delta Y_{t-1}$ & $\begin{array}{l}0.18^{*} \\
(1.98)\end{array}$ & $0.04(0.72)$ & $\begin{array}{l}0.30 * * \\
(4.13)\end{array}$ & $\begin{array}{l}0.02 \\
(0.09)\end{array}$ & $0.04(0.46)$ & $\begin{array}{l}0.32 * * \\
(3.21)\end{array}$ & $-0.06(-0.55)$ & $0.02(0.97)$ \\
\hline $\operatorname{Ln} \Delta I_{t-1}$ & $\begin{array}{l}0.56 \\
(1.28)\end{array}$ & $0.06(0.91)$ & $\begin{array}{l}0.42 * * \\
(2.93)\end{array}$ & $\begin{array}{l}-0.06(- \\
0.18)\end{array}$ & $-0.16(-1.04)$ & $1.50(0.71)$ & $3.52(1.23)$ & $\begin{array}{l}0.50 * * \\
(6.20)\end{array}$ \\
\hline $\operatorname{Ln} \Delta A_{t-1}$ & $\begin{array}{l}0.02 \\
(0.03)\end{array}$ & $\begin{array}{l}-0.48(- \\
1.82)\end{array}$ & $\begin{array}{l}0.09 \\
(0.40)\end{array}$ & $\begin{array}{l}0.15 \\
(0.64)\end{array}$ & $0.42 * *(3.21)$ & $\begin{array}{l}-1.12(- \\
0.52)\end{array}$ & $-2.20(-0.82)$ & $\begin{array}{l}1.42 * * \\
(6.73)\end{array}$ \\
\hline$\hat{e}_{t-1}$ & $\begin{array}{l}-1.09 * *(- \\
3.97)\end{array}$ & $\begin{array}{l}-0.27(- \\
1.03)\end{array}$ & $\begin{array}{l}-0.80 * *(- \\
3.60)\end{array}$ & $\begin{array}{l}-0.86^{* *}(- \\
3.07)\end{array}$ & $\begin{array}{l}-1.33 * *(- \\
7.54)\end{array}$ & $\begin{array}{l}-0.56^{*}(- \\
2.58)\end{array}$ & $\begin{array}{l}-1.20 *(- \\
2.47)\end{array}$ & $\begin{array}{l}-1.13^{* *}(- \\
5.46)\end{array}$ \\
\hline R-square & 0.59 & 0.60 & 0.57 & 0.45 & 0.74 & 0.31 & 0.28 & 0.66 \\
\hline Estimated F- value & $4.63 * *$ & $10.65^{* *}$ & $9.24 * *$ & $5.90 * *$ & $20.93^{* *}$ & $3.18^{*}$ & $2.86^{*}$ & $17.69 * *$ \\
\hline Estimated D-W value & 2.03 & 2.30 & 1.99 & 2.18 & 1.27 & 1.37 & 2.26 & 1.87 \\
\hline $\begin{array}{l}\begin{array}{l}\text { Std. error of the } \\
\text { estimate }\end{array} \\
\end{array}$ & 0.08 & 0.09 & 0.04 & 0.18 & 0.18 & 0.14 & 0.17 & 0.10 \\
\hline \multirow[t]{2}{*}{ Variable } & \multicolumn{8}{|c|}{ Long-run coefficients } \\
\hline & Rice & Bajra & Wheat & Gram & $\begin{array}{l}\text { Rapeseed- } \\
\text { Mustard }\end{array}$ & $\begin{array}{l}\text { Cotton } \\
(\text { Am. })\end{array}$ & Cotton (desi) & Sugarcane \\
\hline Constant & 0.02 & 4.01 & 1.79 & 5.15 & 0.71 & -0.95 & 1.56 & -0.56 \\
\hline $\mathrm{Ln} H P_{t-1}$ & $\begin{array}{l}0.19^{* *} \\
(3.46)\end{array}$ & $\begin{array}{l}-0.03(- \\
0.54)\end{array}$ & $\begin{array}{l}0.04 \\
(1.89)\end{array}$ & $\begin{array}{l}-0.24(- \\
1.85)\end{array}$ & $0.22 *(2.01)$ & $0.06(0.87)$ & $-0.06(-1.33)$ & $\begin{array}{l}0.29 * * \\
(2.88)\end{array}$ \\
\hline $\operatorname{Ln} Y_{t-1}$ & $\begin{array}{l}0.26^{*} \\
(2.58)\end{array}$ & $\begin{array}{l}-0.15 * *(- \\
3.32)\end{array}$ & $\begin{array}{l}0.18^{* *} \\
(2.99)\end{array}$ & $\begin{array}{l}-0.14(- \\
0.61)\end{array}$ & $0.14(0.76)$ & $0.29 *(2.49)$ & $-0.17(-1.43)$ & $0.04(0.95)$ \\
\hline $\operatorname{Ln} I_{t-1}$ & $\begin{array}{l}0.05 \\
(0.16)\end{array}$ & $0.04(0.51)$ & $\begin{array}{l}0.36^{*} \\
(2.53)\end{array}$ & $\begin{array}{l}0.41 \\
(1.71)\end{array}$ & $0.19 *(2.05)$ & $1.28(0.42)$ & $5.35(1.48)$ & $\begin{array}{l}0.47 * * \\
(4.51)\end{array}$ \\
\hline $\operatorname{Ln} A_{t-1}$ & $\begin{array}{l}0.48 \\
(1.36)\end{array}$ & $\begin{array}{l}0.54 * * \\
(3.33)\end{array}$ & $\begin{array}{l}0.18 \\
(0.81)\end{array}$ & $\begin{array}{l}0.22 \\
(0.98)\end{array}$ & $0.30 *(2.24)$ & $-0.47(-0.16)$ & $-4.39(-1.22)$ & $\begin{array}{l}1.03^{* *} \\
(5.74)\end{array}$ \\
\hline R-square & 0.98 & 0.73 & 0.99 & 0.81 & 0.85 & 0.94 & 0.75 & 0.50 \\
\hline Estimated F-value & $495.35 * *$ & $26.10^{* *}$ & $822.40 * *$ & $40.54 * *$ & $52.86^{* * *}$ & $152.56^{* * *}$ & $28.86^{* * *}$ & $8.27 * *$ \\
\hline Estimated D-W value & 2.10 & 2.32 & 1.54 & 2.27 & 2.17 & 1.82 & 1.77 & 1.40 \\
\hline $\begin{array}{l}\text { Std. error of the } \\
\text { estimate }\end{array}$ & 0.08 & 0.12 & 0.04 & 0.40 & 0.26 & 0.15 & 0.18 & 0.12 \\
\hline Estimated ADF value & $-6.57 *$ & $-6.83 *$ & $-5.47 *$ & $-6.84 *$ & $-6.48 *$ & $-6.56^{*}$ & $-5.72 *$ & $-5.08^{*}$ \\
\hline
\end{tabular}

Figures in parentheses are the $\mathrm{t}$ - values of the respective coefficients

* Significant at 5\% probability level. ** Significant at 1\% probability level.

Table.5 Short-run and long-run elasticities for acreage response

\begin{tabular}{|c|c|c|c|c|c|c|}
\hline \multirow[t]{3}{*}{ Crop } & \multicolumn{6}{|c|}{ Acreage Elasticities with respect to } \\
\hline & \multicolumn{2}{|c|}{ Price } & \multicolumn{2}{|c|}{ Yield } & \multicolumn{2}{|c|}{ Irrigation } \\
\hline & Short-run & Long-run & Short-run & Long-run & Short-run & Long-run \\
\hline Rice & $0.02(0.10)$ & $0.19 * *(3.46)$ & $0.18 *(1.98)$ & $0.26 *(2.58)$ & $0.56(1.28)$ & $0.05(0.16)$ \\
\hline Bajra & $0.18 *(2.16)$ & $-0.03(-0.54)$ & $0.04(0.72)$ & $-0.15 * *(-3.32)$ & $0.06(0.91)$ & $0.04(0.51)$ \\
\hline Wheat & $0.01(0.21)$ & $0.04(1.89)$ & $0.30 * *(4.13)$ & $0.18 * *(2.99)$ & $0.42 * *(2.93)$ & $0.36 *(2.53)$ \\
\hline Gram & $0.36(1.28)$ & $-0.24(-1.85)$ & $0.02(0.09)$ & $-0.14(-0.61)$ & $-0.06(-0.18)$ & $0.41(1.71)$ \\
\hline Rapeseed-mustard & $0.40 *(2.60)$ & $0.22 *(2.01)$ & $0.04(0.46)$ & $0.14(0.76)$ & $-0.16(-1.04)$ & $0.19 *(2.05)$ \\
\hline Cotton (Am) & $0.16(1.30)$ & $0.06(0.87)$ & $0.32 * *(3.21)$ & $0.29 *(2.49)$ & $1.50(0.71)$ & $1.28(0.42)$ \\
\hline Cotton (desi) & $0.22(1.42)$ & $-0.06(-1.33)$ & $-0.06(-0.55)$ & $-0.17(-1.43)$ & $3.52(1.23)$ & $5.35(1.48)$ \\
\hline Sugarcane & $0.35 *(2.52)$ & $0.29 * *(2.88)$ & $0.04(0 . .95)$ & $0.02(0.97)$ & $0.50 * *(6.20)$ & $0.47^{* * *}(4.51)$ \\
\hline
\end{tabular}

Figures in parentheses are the $\mathrm{t}$ - values of the respective coefficients

* Significant at $5 \%$ probability level. ** Significant at $1 \%$ probability level. 
The results of the Table 4 revealed that in the long-run multiple regressions, the value of $\mathrm{R}$ square has been observed to be $0.99,0.98$ and 0.94 in case of wheat, rice and cotton (Am,) respectively, while for other crops it ranged from 0.50 to.85. High explanatory power of the model is further supported by highly significant estimated value of F-statistic which was significant at 1 per cent or 5 per cent level of significance for all the crops. The same pattern regarding estimated Fstatistic was observed in the error correction model also. However, the values of R-square were observed to be not so encouraging in the error correction model. Its value was observed to be as low as 0.28 in case of cotton (desi) in the error correction model.

It can be observed from the results that the coefficient of the error correction term carries the expected negative sign and it is highly significant (except bajra) at $1 \%$ level of significance in case of wheat, gram, rapeseedmustard, cotton (Am.) and sugarcane. However, in case of cotton (Am.) and cotton (desi) it is significant at 5\% level of significance. The significance of the error correction term supports co integration and suggests the existence of long-run steady state equilibrium between the acreage under the respective crops and explanatory variables finally included in the model. The error correction term at lag one is higher in the case of rice, rapeseed-mustard, cotton (desi) and sugarcane as compared to the rest of the crops. This shows that short-run fluctuations in acreage under rice, rapeseed-mustard, cotton (desi) and sugarcane is quickly adjusted to its long-run trend as compared to other crops. However, the error correction coefficient is minimum in case of bajra indicating slow speed of adjustment.

The long-run acreage response to lagged price is positive and significant in the case of rice, rapeseed-mustard and sugarcane with elasticity values $0.19, \quad 0.22$ and 0.29 , respectively. In case of other crops except bajra and gram, very low positive but nonsignificant values have been observed. In the short-run, lagged price elasticities are found to be positive for all the crops. However, the positive significant values have been observed in case of rapeseed-mustard, sugarcane and bajra with values $0.40,0.35$ and 0.18 , respectively, while in the case of rice and wheat, elasticities are found to be very low and non-significant which indicates that shortrun price fluctuations have no impact on acreage under these crops.

The long-run acreage response to lagged year yield is found to be positive and significant in case of rice, wheat and cotton (Am.) with values as $0.26,0.18$ and 0.29 , respectively, whereas yield is impacting acreage negatively but non significantly in case of bajra, gram and cotton (desi). The similar pattern has also been observed in case of short-run elasticities too. Both wheat and cotton (Am.) are found to be more responsive to yield as compared to price.

Irrigation elasticity has been observed to be positive for all the crops in the long-run, while it is positive for all the crops except gram and rapeseed-mustard in the short-run. However, only wheat and sugarcane are found to be positively and significantly responsive to irrigation in the long-run as well as in the short-run. In the case of rice, cotton (Am.) and cotton (desi), irrigation elasticity is positive but not statistically significant, while in the case of gram and rapeseed-mustard, it has non-significant negative values. Coefficient representing lagged area attained positive sign in all the crops except cotton (Am.) and cotton (desi) in the long-run as well as in the short-run. However, a positive significant coefficient has been observed in case of bajra, rapeseed-mustard and sugarcane. This shows that lagged acreage 
under these crops is an important factor in determining the current acreage decision of the farmer.

Table 5 depicts the short-run and long-run acreage elasticities with respect to price, yield and irrigation. From the results it is evident that long-run acreage response of rice to price and yield is positive and significant. In case of wheat, yield and irrigation are positively and significantly affecting the acreage in the longrun as well as in the short run. Price and irrigation elasticities are positive and significant for rapeseed-mustard and sugarcane in the long-run while for cotton (Am.), yield elasticity is positive and significant in the short-run as well as in the long-run. Non-significant and low rather negative elasticities have been observed in case of bajra, gram and cotton (desi).

The present study was undertaken for the state of Haryana to estimate the acreage response functions for major crops and to compare the short-run and long-run supply elasticities of major crops within the framework of co integration and error correction model. The earlier approach given by Nerlove (1958), which has been used by many researchers to estimate supply response in India and abroad, poses the problem of spurious regressions in case of non-stationary time series data (Gujrati, 1995 and Greene, 2008). Cointegration analysis can be used with nonstationary data to avoid spurious regressions (Banerjee, et al., 1993) when combined with error correction models; it offers a means of obtaining consistent yet distinct estimates of both long-run and short-run elasticity.

The results of the study revealed that the estimated ADF statistic computed for the residuals obtained from the multiple regressions between the area under the crop and the explanatory variables like lagged harvest price, lagged yield, lagged irrigated area and lagged area for the considered crops were found to be significant in all the crops, thus rejecting the null hypothesis of no co integration between the area and considered explanatory variables and implied a valid long-run relationship. After the long-run relationship has been confirmed, an error correction model (ECM) as provided in equation (2.10) including only those explanatory variables which have been finally considered in the long-run co integration and the lagged residuals obtained from these multiple co integrating regressions as an additional explanatory variable was developed. The negative sign and significance of the error correction term (Table 4) supports co integration and suggests the existence of long-run steady state equilibrium between the acreage under the respective crops and explanatory variables finally included in the model. The obtained results for short-run and long-run elasticities with respect to price, yield and irrigation (Table 5) suggest that non-price factors like irrigation and yield are dominating towards acreage response as compared to price as in earlier studies (Krishna, 1963; Krishna and Rao, 1967; Maji et al., 1971; Cummings, 1975; Askari and Cummings, 1977; Narayana et al., 1981; Rao, 2004 and Mythili, 2008).

It is concluded that the long-run acreage response to lagged price was positive and significant in the case of rice, rapeseedmustard and sugarcane with elasticity values $0.19,0.22$ and 0.29 , respectively. In case of other crops except bajra and gram, very low positive but non-significant price elasticities have been observed. In the short-run, lagged price elasticities were found to be positive for all the crops. However, the positive significant values have been observed in case of rapeseed-mustard, sugarcane and bajra only. The long-run acreage response to lagged year yield was found to be positive and significant in case of rice, wheat and cotton 
(Am.) with elasticity values $0.26,0.18$ and 0.29 , respectively. Irrigation elasticity has been observed to be positive for all the crops in the long-run, while it is positive for all the crops except gram and rapeseed-mustard in the short-run. However, only wheat and sugarcane are found to be positively and significantly responsive to irrigation in the long-run as well as short-run.

\section{Acknowledgement}

I express my deep sense of gratitude with reverence to the Head, ICAR-NBSS \& LUP, Regional centre, New Delhi for their encouragement and kind support in my work. I seize this opportunity to express my deep sense of gratitude indebtedness, appreciation and heartfelt regards for my major advisor Dr. (Mrs.) Veena Manocha, Joint Director (Statistics), Directorate of Human Resource Management, for her constructive suggestions, able guidance and constant encouragement. I want to express my heartfelt gratitude to her for giving me an opportunity to work with him in a friendly environment. I would like to acknowledge the help and support of my seniors. I also want to express sincere thanks to Dr. S.K. Goyal, Dept. of Business Management for providing me support in using the E-views software. I proudly take this opportunity to thank CCS Haryana Agricultural University, Hisar for providing me facilities from time to time during my studies.

At last but not least, I must convey my thanks to almighty.

\section{References}

Adam, C.S. 1992. Recent Developments in Econometric Methods: An Application to the Demand for Money in Kenya. African Econ. Res. Consortium (AERC). 15: $1-52$.
Askari, H. and Cummings, J.T. 1977. Estimating Agricultural Supply Response with the Nerlove Model. International Economic Review. 18(2): 257-292.

Banerjee, A., Dolado, J., Gabriraith, J. \& Hendry, D. 1993. Co-integration, Error Correction and the Econometric Analysis of non-stationary data. Oxford: Oxford University Press.

Behrman, J.R. 1968. Supply Response in Underdeveloped Agriculture: A Case Study of Four Major Annual Crops in Thailand 1937-63. Amsterdam: North Holland Pub. Co.

Cummings, J.T. 1975. Cultivator Market Responsiveness in Pakistan-Cereal and Cash Crops. Pakistan Development Review. 14(3): 261-273.

Deb, Surajit. 2003. Terms of trade and Supply response of Indian agriculture: Analysis in Co-integration Framework. Working Paper No. 115. Centre for Development Economics, Delhi School of Economics, Delhi.

Engle, R.F. and C.W.J. Granger, 1987. Cointegration and Error Correction: Representation, Estimation and Testing. Econometrica. 55: 251-76.

Greene, W.H. 2008. Econometric Analysis, Sixth edition, New Jersey: Pearson Education Inc.

Gujrati, D.N. 1995. Basic Econometrics. New York: McGraw- Hill Publishers.

Johnston, J. 1984. Econometric Methods. New York: McGraw- Hill Book company

Johnston, J. and DiNardo, J. 1997. Econometric Methods. $4^{\text {th }}$ Edn. McGraw Hill, New York.

Krishna, J. and Rao, M.S. 1967. Price Expectation and Acreage Response for Wheat in Uttar Pradesh. Indian Journal of Agricultural Economics. 20(1): 2025. 
Krishna, R. 1963. Farm Supply Response in India-Pakistan: A Case Study of the Punjab Region. The Economic Journal. 73(291): 477-487.

Krishna, R. 1982. Growth, Price Policy and Equity. Food Research Institute Studies. 18(3).

Maji, C.C., Jha, D and Venkataramanan, L.S. 1971. Dynamic supply and demand models for better estimations and projections: An econometric study for major food grains in the Punjab region. Indian Journal of Agricultural Economics. 26: 21-22.

Muchapondwa, E. 2008. Estimation of the aggregate agricultural supply response in Zimbabwe: The ARDL approach to cointegration. Working Paper Number 90, School of Economics, University of Cape Town.

Mythili, G. 2008. Acreage and Yield Response for Major Crops in the Pre and Post-Reform Periods in India: A Dynamic Panel Data Approach. PP Series 061, Indian Gandhi Institute of Development of Research, Mumbai.

Narayana, N.S.S. and Parikh, K.S. 1981. Estimation of Farm Supply Response and Acreage Allocation: A Case Study of Indian Agriculture. Reasearch Report - 81-1, International Institute for Applied Systems Analysis.

Nerlove, M. 1958. The Dynamics of Supply: Estimation of Farmers' Response to
Price: $1^{\text {st }}$ Edn. The John Hopkins University Press, Balti-More.

Nerlove, M. and Bachman, K.L. 1960. The Analysis of Changes in Agricultural Supply: Problems and Approaches. Journal of Farm Economics. 42: 531554.

Niemi, J. 2003. Cointegration and Error Correction Modelling of Agricultural Commodity Trade: The Case of ASEAN Agricultural Exports to the EU. Agric. Food Sci. Finland. 12: 1-164.

Nowshirvani, V.F. 1971. Land Allocation under Uncertainty in Subsistence Agriculture. Oxford Economic Papers. 23(3):445

Rao, Chandrasekhara N. 2004. Aggregate Agricultural supply response in Andhra Pradesh. Indian Journal of Agricultural Economics. 59(1): 91-104.

Sadoulet, E. and de Janvry, A. 1995. Quantitative Development Policy Analysis. The John Hopkins University Press, Balti-More.

Tambi, N.E. 1999. Cointegration and Error Correction Modelling of Export Supply in Cameroon. Agric. Econ. Elsevier. 20: 57-67.

Tripathi, A.2008. Estimation of Agricultural Supply Response by Cointegration Approach, A Report Submitted Under Visiting Research Scholar Programme 2008, Indira Gandhi Institute of Development Research, Goregaon (E), Mumbai.

\section{How to cite this article:}

Vikas, Veena Manocha and Goyal, S.K. 2018. Estimation of Acreage Response of Major Crops in Haryana using Co-integration Approach. Int.J.Curr.Microbiol.App.Sci. 7(03): 2890-2903. doi: https://doi.org/10.20546/ijcmas.2018.703.334 